\title{
Chemical Composition, Toxicity and Antidermatophytic Activity of Essential Oil of Trachyspermum ammi
}

\author{
NEETU JAIN* ${ }^{*}$ M. SHARMA, S. C. JOSHI ${ }^{1}$ AND U. KAUSHIK ${ }^{1}$ \\ Department of Botany, Laboratory of Medical Mycology and Plant Pathology, ${ }^{1}$ Department of Zoology, University of Rajasthan, \\ Jaipur-302 004, India
}

\author{
Jain, et al.: Toxicity of T. ammi Essential oil
}

\begin{abstract}
Present study was designed to explore the essential oil of Trachyspermum ammi and its fractions against fungi causing dermatophytoses in humans along with toxicological evaluation on mice. The chemical composition of T. ammi essential oil analysed by gas chromatography and gas chromatography-mass spectrometry presented 20 compounds. Thymol was found to be the major compound $(58.88 \%)$ followed by p-cymene $(24.02 \%), \gamma$-terpinene (13.77\%) and $\beta$-pinene (1.90\%). Antidermatophytic activity was determined by disc diffusion method and minimum inhibitory concentration. Maximum zone of inhibition was observed against Chrysosporium tropicum $(63.83 \pm 0.166 \mathrm{~mm})$ followed by Trichophyton simii $(57 \pm 0.288 \mathrm{~mm})$, Trichophyton rubrum $(51.33 \pm 0.333 \mathrm{~mm})$ and Chrysosporium indicum $(45 \pm 0.577 \mathrm{~mm})$. Minimum inhibitory concentration of $T$. ammi oil ranged from 0.025 to $0.5 \mu \mathrm{l} / \mathrm{ml}$ against test fungi. $T$. ammi oil was further subjected for fraction separation through Buchii's glass oven equipment. Five fractions were separated at different temperature conditions labelled as $\mathrm{TA}^{\mathrm{I}}-\mathrm{TA}^{\mathrm{V}}$. Maximum effects were seen in case of $\mathrm{TA}^{\mathrm{IV}}$ and $\mathrm{TA}^{\mathrm{V}}$ fractions. Excellent results of $\mathrm{TA}^{\mathrm{V}}$ was observed against Microsporum gypseum $(0.015 \pm 0.002 \mu \mathrm{l} / \mathrm{ml})$ followed by Microsporum canis $(0.017 \pm 0.002 \mu \mathrm{l} / \mathrm{ml})$, Trichophyton rubrum $(0.02 \pm 0.000 \mu \mathrm{l} / \mathrm{ml})$ and Candida albicans $(0.05 \pm 0.003 \mu \mathrm{l} / \mathrm{ml})$. No work on T. ammi essential oil fractions, their antidermatophytic activity and toxicological behaviour on Swiss albino mice were reported till date. Acute dermal irritation assay was applied for toxicological studies on albino mice. Low concentration up to $3 \%$ did not show any irritation on mice skin. At $5 \%$ concentration 3 mice showed mild erythema, while on $7 \%$ concentration all five mice exhibited well defined erythema. Present study concluded that essential oil of $T$. ammi and its fractions have strong antidermatophytic properties with no side effect at low concentrations and thus could produce alternative therapeutics to current antibiotics.
\end{abstract}

Key words: Dermatophytes, MIC, mice, toxicology, essential oil, Trachyspermum ammi

Trachyspermum ammi L belonging to family Apiaceae is an important commercial ingredient for the food and flavouring industry. It is a known as a popular aromatic herb and spice that grows in Egypt, Persia, Bangladesh, Afghanistan, Ethiopia and India ${ }^{[1]}$. Now a days, the Ajwain fruit oil is chiefly employed for flavouring sausages, meat, canned goods, perfumes, mouth preparation and liquors. The T. ammi fruits have many folk medicinal activities like cytotoxicity ${ }^{[2]}$, antimicrobial ${ }^{[3-5]}$, antiinflammatory, antioxident $t^{[6]}$, antipyretic, analgesia, diuretic, antitermitic ${ }^{[7]}$, antiviral ${ }^{[8]}$, anticipative, anticandidial activity ${ }^{[9]}$, anthelmintic ${ }^{[10]}$ and carminative effects. Its effectiveness against kidney stones was studied by Ahsan et al. ${ }^{[11]}$.

Essential oil of aromatic plants has been recognized for many years as a major source of pharmaceutical agents and food additives. In recent years there has been a gradual revival of interest in the use of medicinal products such as essential oil and other botanical products in response to the ever increasing incidence of adverse side effects associated with conventional drugs, high cost medicines, long duration of treatment time and emergence of resistance to antifungal drugs especially in case of dermatophytoses. Dermatophytoses are superficial infections of keratinized tissue caused by organism of three genera of fungi known as

This is an open access article distributed under the terms of the Creative Commons Attribution-NonCommercial-ShareAlike 3.0 License, which allows others to remix, tweak, and build upon the work non-commercially, as long as the author is credited and the new creations are licensed under the identical terms

Accepted 04 December 2017

Revised 21 April 2017

Received 08 December 2016

Indian J Pharm Sci 2018;80(1):135-142 
dermatophyton ${ }^{[12]}$. The dermatophytes represent more than 40 closely related species classified in three genera: Microsporum, Trichophyton and Epidermophyton. The skin infection due to dermatophytes has become a significant health problem affecting children, adolescent and adults. Recently, there has been an increase in the incidence of fungal infections in developing countries. This may be owing to frequent usage of antibiotics, environmental condition, immunosuppressive drugs and various other conditions like organ transplantation, lymphomas, leukaemia and human immunodeficiency virus $^{[13]}$. Fungal infections in human are frequently observed during those seasons of the year when the environmental temperature and relative humidity are pretty high ${ }^{[14]}$. With its temperature exceeding even $46^{\circ}$, Jaipur has a dry climate in summer. Its humidity level during monsoon is also very high. These climatic conditions are amenable to the incidence of the fungi and consequently the disease ${ }^{[15]}$. Present work deals with the chemical analysis of T. ammi essential oil, separation of essential oil fractions, screening of antidermatophytic activity and toxicological behaviour on Swiss albino mice.

\section{MATERIAL AND METHODS}

\section{Oil extraction method:}

Fruits of T. ammi were brought from an authorized Ayurvedic store of medicinal plants at Jaipur in India. For extraction of essential oil, fruits were macerated with a small quantity of distilled water and the thus produced slurry was distilled with the hydro-distillation unit (Clevenger's apparatus) for 7-8 h. Essential oil collected in tubes was dried with anhydrous sodium sulphate. The moisture free oil was then stored in amber colored bottles and kept in a refrigerator. Essential oil of T. ammi was further subjected in the glass bulbs of Buchii's glass oven equipment for the separation of its ingredients at different temperature intervals. First fraction was separated at $160^{\circ}$. Remaining ones were separated after $20-25^{\circ}$ temperature interval to the preceding fraction.

\section{Microorganism for in vitro studies:}

Antifungal properties of $T$. ammi were investigated against most commonly reported and isolated dermatophytes, keratinophilic fungi and Candida albicans in Jaipur area. Trichophyton rubrum, T. verrucosum, Microsporum gypseum and C. albicans were isolated from infected skin scrapings of tinea patients from the SMS Hospital, Jaipur during survey of dermatophytoses while M. fulvum, M. canis, Fusarium verticilloides, Chrysosporium tropicum and C. indicum were isolated from soil samples through To-Ka-Va hair baiting technique ${ }^{[16]}$. All these fungi were identified through standard protocols. These fungi were maintained on Sabouraud's dextrose agar medium.

\section{Gas chromatography (GC) and gas chromatography- mass spectrometry (GC-MS) analysis:}

Quantitative analysis of the essential oil was carried out using a Shimadzu GC-2010. Nitrogen was used as carrier gas at 10 psi inlet pressure with FID and Omega SPTm column $(30.0 \mathrm{~m} \times 0.25 \mathrm{~mm}$ ID, film thickness $0.25 \mu \mathrm{m})$. Injector and detector temperatures were $270^{\circ}$ and $280^{\circ}$, respectively. Column temperature programmed from $80^{\circ}$ ( 2 min hold), $80^{\circ}$ to $180^{\circ}$ at $4^{\circ} / \mathrm{min}$ and $180^{\circ}$ to $230^{\circ}$ at $6^{\circ} / \mathrm{min}$ with-hold time of 6 and $19 \mathrm{~min}$, respectively. The flow rate of carrier gas was $1.21 \mathrm{ml} / \mathrm{min}$ and split ratio was 1:80. The data were processed on GC solutions software for oil composition.

GC-MS data was also obtained on a Shimadzu GCMSQP-2010 plus system using same column. Helium was used as carrier gas. Injector, mass detector, ion source temperatures, column temperature and other condition were same as given in GC. EI source and mass range were $70 \mathrm{eV}$ and 40-850 AMU, respectively. Compounds were identified by using Willey, NIST and Perfumery libraries. Compounds were identified by using Willey, NIST and Perfumery libraries. The compound identification was finally confirmed by comparison of their relative retention indices with literature values.

\section{Screening of oil:}

The filter paper disc method ${ }^{[17]}$ was employed for screening the essential oils against dermatophytes. Standard size Whatman No. 1 filter paper discs of $6.0 \mathrm{~mm}$ in diameter, sterilized by dry heat at $140^{\circ}$ in an oven for $1 \mathrm{~h}$ were used to determine antifungal activity. Twenty millilitres of sterilized Sabouraud's dextrose agar medium was taken in each autoclaved Petri-dish and allowed to solidify. Fungal spore suspension was prepared in sterilized distilled water by transferring a loopful of $15 \mathrm{~d}$ old culture. The $1 \mathrm{ml}$ of spore suspension of approximately 0.5 to $5 \times 10^{4}$ colonyforming unit $(\mathrm{CFU}) / \mathrm{ml}$ was spread over the respective agar medium plates. Sterilized filter paper discs were soaked in neat undiluted $(100 \%)$ as well as in diluted oil (25, 50 and $75 \%$ concentrations). Dilution was done 
in acetone. An oil saturated disc was placed on an agar plate containing fungal spore suspension. Griseofulvin, ketoconazole and itraconazole were used as standard drugs. These plates were incubated at $37^{\circ}$ for $72 \mathrm{~h}$. Five replicates were kept in each case and the average values of each one was determined and inhibition zones were observed. The antifungal activity was determined by measuring the inhibition zone around the disc. The activity of oil was measured using the following Eqn., activity index = inhibition zone of the sample/inhibition zone of the standard.

\section{Semisolid agar antifungal susceptibility method:}

Semisolid agar antifungal susceptibility testing method of Provine and Hadley ${ }^{[18]}$ was carried out in brain heart infusion agar (BHIA, HiMedia) for the determination of minimum inhibitory concentration (MIC). BHIA was prepared according to manufacturer's instruction. Sterile swab dipped into sterile Tween- 80 was used to pick the pure colony of yeast. This was then suspended in 3-4 $\mathrm{ml}$ of sterile normal saline and vortexed. The turbidity of the homogenous suspension was adjusted to $\sim 0.5 \mathrm{McF}$ arland standard. Similarly inoculum was prepared for filamentous fungi (3-7 d old slant at $37^{\circ}$ on potato dextrose agar).

The semisolid agar tubes containing known concentrations of test oil as well as oil-free control, prepared in triplet, were inoculated with one loopful (HiMedia Flexiloop 4) of 0.5 McFarland adjusted culture by inserting the loop deep within the semisolid agar. The tubes were incubated at $37^{\circ}$ for $48 \mathrm{~h}$ for C. albicans and $72 \mathrm{~h}$ for dermatophytes. For present investigation, 0.025 to $5 \mu \mathrm{l} / \mathrm{ml}$ concentrations of pure oil and its fractions were tested.

End point determination was carried out according to the Clinical and Laboratory Standards Institute (NCCLS/CLSI) guidelines, M27-A and M38-A. The growth was compared to that of oil-free control and scored by visual inspection as follows: +4 growth same as control; +3 slight decrease in growth; +2 significant reduction in growth (reduction $80 \%$ in yeast and $50 \%$ in filamentous); +1 slight growth or few visible hyphal fragments; 0: no growth.

\section{Toxicological studies of essential oil:}

The acute dermal irritation assay of Draize ${ }^{[19]}$ was applied for toxicological studies of the essential oil. All this work was done in accordance with the animal ethical guidelines. The permission for which was obtained from the institutional animal ethics committee (1678/GO/9/12/CPCSEA). A group of 2025 Swiss albino mice was screened for this study. All the mice selected for the study were good in health. The mice exhibiting sniffles, hair loss, loose stools or apparent loss were rejected and replaced. Only the mice considered suitable for the use were selected for the study. Prior to treatment initiation, all mice were weighted. Their weight ranged from 20-25 g. Within $24 \mathrm{~h}$ before the test, the fur was removed from the dorsal area of the trunk of each mice, caring to avoid abrading of the skin. Observation was recorded one hour after the application of oil, at 24, 48 and on $72 \mathrm{~h}$ after application. The scoring system examined the skin for the presence of erythema and edema. The former was graded as 0 for no erythema, with erythema scores of 1 for very slight, 2 for well defined, 3 for moderate to severe and 4 for severe to eschar formation. Edema was scored in a similar manner with 0 indicating none, 1 - very slight, 2- slight, 3- moderate and 4- severe. A score for each animal was determine using the immediate, 24 , 48 and $72 \mathrm{~h}$ observations for calculations and dividing by four. The primary irritation index (PII) is the sum of the scores for all of the animal scores that is divided by number of observations primary dermal irritation index (PDII): 0.0- non irritation, $>0.0-0.5$ - negligible irritant, $>0.5-2.0$ - mild irritant, $>2.0-5.0$ - moderate irritant, $>5.0-8.0$ - severe irritant.

\section{Statistical analysis:}

Statistical analysis was carried by one way ANOVA following multiple comparison tests Tukey's method. Data is expressed as mean and SEM.

\section{RESULTS AND DISCUSSION}

In present investigation, GC and GC-MS analysis of T. ammi essential oil showed presence of 20 compounds for $100 \%$ of total oil as listed in their elution (fig. 1). Thymol was found as a major compound (58.88 $\%)$ followed by p-cymene (24.02\%), $\gamma$-terpinene $(13.77 \%), \beta$-pinene $(1.90 \%), \alpha$-thujene $(0.31 \%)$ and myrcene $(0.35 \%)$. Other compounds include $\alpha$-pinene $(0.16 \%), \alpha$-terpinene $(0.17 \%)$, terpinen-4-ol $(0.08 \%)$ and $\alpha$-terpineol $(0.08 \%$; Table 1$)$. Percent occurrence of eugenol was found 0.01 .

The data of disc diffusion technique incorporated in Table 2 shows that in the case of T. rubrum, the maximum inhibition zone $(51.33 \pm 0.333 \mathrm{~mm})$ was found when undiluted oil was used. Other concentration like 75,50 and $25 \%$ oils also exhibited 


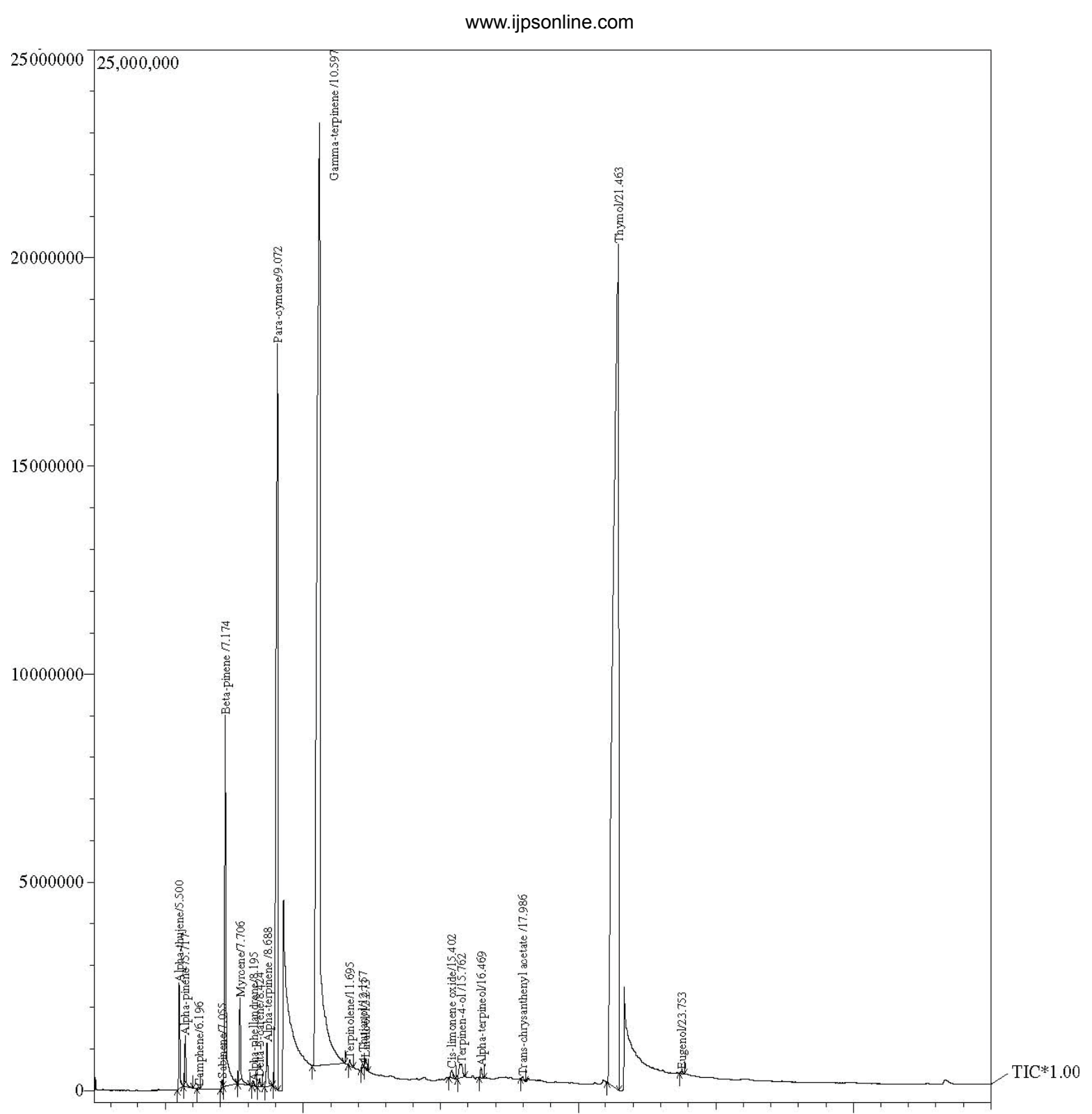

Fig. 1: GC-MS analysis of T. ammi essential oil Thymol was found as a major compound $(58.88 \%)$ followed by p-cymene $(24.02 \%)$, $\gamma$-terpinene $(13.77 \%)$, $\beta$-pinene $(1.90 \%)$, $\alpha$-thujene (0.31 \%) and myrcene (0.35\%)

more promising activity (inhibition zone $=47 \pm 0.577$, $39.33 \pm 0.333$ and $29.66 \pm 0.666 \mathrm{~mm}$, respectively) than that of griseofulvin (inhibition zone $=28 \pm 0.577 \mathrm{~mm}$ ). In the case of $T$. simii, all the four concentration of oil showed prominent antifungal activity as compared to griseofulvin $(24 \pm 0.577 \mathrm{~mm})$. The maximum inhibition zone $57 \pm 0.288 \mathrm{~mm}$ was formed when undiluted oil was used. Chrysosoprium indicum was found to be most susceptible fungus to $T$. ammi oil than standard ketoconazole. The maximum inhibition zone $45 \pm 0.577$ $\mathrm{mm}$ and activity index $(2.64 \pm 0.033)$ were observed when undiluted $T$. ammi was used. Twenty five percent oil too showed immense inhibition action (inhibition zone $=22 \pm 1.154 \mathrm{~mm} ; \mathrm{AI}=1.29 \pm 0.068$ ) as compared to ketoconazole $(\mathrm{IZ}=17 \pm 0.577 \mathrm{~mm})$.
Undiluted T. ammi exhibited broad spectrum activity against selected dermatophytes and other related keratinophilic fungi (Table 3). MIC was determined by modified micro broth dilution method. Its maximum activity was noticed against $T$. verrucosum and T. rubrum (MIC $0.025 \pm 0.000 \mu \mathrm{l} / \mathrm{ml}$ ) followed C. albicans $(0.20 \pm 0.000 \mu \mathrm{l} / \mathrm{ml}), \quad F$. verticilloides $(0.233 \pm 0.033 \mu \mathrm{l} / \mathrm{ml})$, M. fulvum $(0.266 \pm 0.033 \mu \mathrm{l} / \mathrm{ml})$ and $M$. gypseum $(0.5 \pm 0.000 \mu \mathrm{l} / \mathrm{ml})$.

Five different fraction of $T$. ammi were separated and labeled as TA, TA ${ }^{\mathrm{II}}, \mathrm{TA}^{\mathrm{III}}, \mathrm{TA}^{\mathrm{IV}}$ and $\mathrm{TA}^{\mathrm{V}}$ (Table 4). These fractions were separated on the basis of boiling point of compounds. Among all these fractions, $\mathrm{TA}^{\mathrm{V}}$ was found to be an excellent antidermatophytic fraction. Its maximum activity was found against 
M. gypseum $(0.015 \pm 0.002 \mu \mathrm{l} / \mathrm{ml})$ and $M$. canis $(0.017 \pm$ $0.002 \mu \mathrm{l} / \mathrm{ml})$ followed by T. rubrum $(0.02 \pm 0.000 \mu \mathrm{l} / \mathrm{ml})$ and $C$. albicans $(0.05 \pm 0.003 \mu \mathrm{l} / \mathrm{ml})$. $\mathrm{TA}^{\mathrm{IV}}$ fraction also showed marvellous activity against all the test fungi. MIC of this fraction was found to be $0.133 \pm$ $0.033 \mu \mathrm{l} / \mathrm{ml}$ against $M$. canis, $0.026 \pm 0.002 \mu \mathrm{l} / \mathrm{ml}$ against $M$. gypseum, $0.050 \pm 0.000 \mu \mathrm{l} / \mathrm{ml}$ against $T$. rubrum and $0.053 \pm 0.003 \mu \mathrm{l} / \mathrm{ml}$ against $C$. albicans.

TABLE 1: CHEMICAL COMPOSITION OF T. AMMI ESSENTIAL OIL

\begin{tabular}{|c|c|c|c|c|c|}
\hline Peak\# & R. Time & $\mathbf{R I}$ & Area & Area \% & Name \\
\hline 1 & 7.243 & 925 & 428373 & 0.3091 & a-Thujene \\
\hline 2 & 7.494 & 932 & 231036 & 0.1667 & a-Pinene \\
\hline 3 & 8.034 & 946 & 7823 & 0.0056 & Camphene \\
\hline 4 & 8.961 & 971 & 24359 & 0.0176 & Sabinene \\
\hline 5 & 9.121 & 975 & 2641134 & 1.9056 & B-Pinene \\
\hline 6 & 9.670 & 991 & 498781 & 0.3599 & Myrcene \\
\hline 7 & 10.267 & 1004 & 17221 & 0.0124 & a-Phellandrene \\
\hline 8 & 10.475 & 1010 & 49177 & 0.0355 & $\Delta$-3-Carene \\
\hline 9 & 10.769 & 1016 & 248690 & 0.1794 & a-Terpinene \\
\hline 10 & 11.362 & 1025 & 33296066 & 24.0228 & p-Cymene \\
\hline 11 & 12.830 & 1061 & 19093349 & 13.7757 & $\mathrm{\gamma}$-Terpinene \\
\hline 12 & 13.954 & 1087 & 34845 & 0.0251 & Terpinolene \\
\hline 13 & 14.427 & 1098 & 55083 & 0.0397 & 4-Thujanol \\
\hline 14 & 14.537 & 1101 & 71163 & 0.0513 & Linalool \\
\hline 15 & 17.598 & 1170 & 17976 & 0.0130 & $\begin{array}{l}\text { Cis-limonene } \\
\text { oxide }\end{array}$ \\
\hline 16 & 18.390 & 1178 & 123717 & 0.0893 & Terpinen-4-ol \\
\hline 17 & 19.508 & 1194 & 119369 & 0.0861 & a-Terpineol \\
\hline 18 & 20.634 & 1228 & 18885 & 0.0136 & $\begin{array}{l}\text { Trans- } \\
\text { chrysanthenyl } \\
\text { acetate }\end{array}$ \\
\hline 19 & 24.402 & 1306 & 81612379 & 58.8826 & Thymol \\
\hline \multirow[t]{2}{*}{20} & 25.893 & 1360 & 12423 & 0.0090 & Eugenol \\
\hline & & & 138601849 & 100.00 & \\
\hline
\end{tabular}

MIC of $\mathrm{TA}^{\mathrm{III}}$ fraction was found to be $0.050 \pm$ $0.000 \mu \mathrm{l} / \mathrm{ml}$ against T. rubrum, $0.053 \pm 0.003 \mu \mathrm{l} / \mathrm{ml}$ against $M$. gypseum, $0.133 \pm 0.033 \mu \mathrm{l} / \mathrm{ml}$ against M. canis and $0.233 \pm 0.033 \mu 1 / \mathrm{ml}$ against $C$. albicans. MIC of TA ${ }^{\text {II }}$ fraction was found to be $0.1 \pm 0.033 \mu \mathrm{g} / \mathrm{ml}$ against M. gypseum, $0.233 \pm 0.033 \mu \mathrm{g} / \mathrm{ml}$ against $T$. rubrum, $0.333 \pm 0.033 \mu \mathrm{l} / \mathrm{ml}$ against $M$. canis and $0.533 \pm 0.033$ $\mu \mathrm{l} / \mathrm{ml}$ against $C$. albicans. TA ${ }^{\mathrm{I}}$ fraction showed slightly less activity as compared to other T. ammi fractions.

Acute dermal irritation assay, the toxicological studies involved five concentration of oil on albino mice. Each concentration was applied on five individual healthy mice. Low concentration up to $3 \%$ did not show any irritation on mice skin. At $5 \%$ concentration 3 mice showed mild erythema, which disappeared on $72 \mathrm{~h}$ observation whereas on $7 \%$ concentration, all five mice exhibited well defined erythema up to $72 \mathrm{~h}$ of the observation (Table 5). Therefore $7 \%$ oil was placed in grade III category of allergenicity rating (Table 6).

T. ammi is an important medicine plant, which possesses both medicinal and therapeutic properties. T. ammi oil was analyzed using GC and GC-MS and the components thereof were identified on the basis of their RI values as well as by comparison of their mass spectra with those reported in literature. The essential oil is composed of fatty acid as well as many polar and nonpolar compounds. Such a high antimicrobial activity of essential oil may be due to presence of high concentration of polar compounds ${ }^{[20]}$. Chemical analysis of $T$. ammi oil showed thymol as a major component. Similar results were observed by various researchers ${ }^{[21-23]}$. Antimicrobial activities are mostly

TABLE 2: COMPARISON OF EFFICACY OF T. AMMI OIL WITH COMMERCIAL ANTIFUNGAL DRUGS

\begin{tabular}{|c|c|c|c|c|c|c|c|c|c|c|c|c|c|c|}
\hline \multirow{4}{*}{$\begin{array}{l}\text { Concent } \\
\text { rations } \\
\text { of oil }\end{array}$} & \multicolumn{14}{|c|}{ Test of fungi } \\
\hline & \multicolumn{4}{|c|}{ Trichophyton rubrum } & \multicolumn{4}{|c|}{ Trichophyton simii } & \multicolumn{2}{|c|}{$\begin{array}{c}\text { Chrysosporium } \\
\text { indicum }\end{array}$} & \multicolumn{4}{|c|}{ Chrysosporium tropicum } \\
\hline & \multirow{2}{*}{ IZ } & \multicolumn{3}{|c|}{ Al } & \multirow{2}{*}{ IZ } & \multicolumn{3}{|c|}{$\mathrm{Al}$} & \multirow{2}{*}{ IZ } & \multirow{2}{*}{$\frac{\mathrm{Al}}{\mathrm{TC} / \mathrm{K}}$} & \multirow{2}{*}{ IZ } & \multicolumn{3}{|c|}{$\mathrm{Al}$} \\
\hline & & $\mathrm{TC} / \mathrm{G}$ & $\mathrm{TC} / \mathrm{I}$ & $\mathrm{TC} / \mathrm{K}$ & & $\mathrm{TC} / \mathrm{G}$ & $\mathrm{TC} / \mathrm{I}$ & $\mathrm{TC} / \mathrm{K}$ & & & & $\mathrm{TC} / \mathrm{G}$ & $\mathrm{TC} / \mathrm{I}$ & $\mathrm{TC} / \mathrm{K}$ \\
\hline $25 \%$ & $\begin{array}{c}29.66 \\
\pm 0.666\end{array}$ & $\begin{array}{c}1.05 \\
\pm 0.023\end{array}$ & $\begin{array}{c}1.41 \\
\pm 0.032\end{array}$ & $\begin{array}{c}0.58 \\
\pm 0.012\end{array}$ & $\begin{array}{c}32 \\
\pm 0.557\end{array}$ & $\begin{array}{c}1.33 \\
\pm 0.024\end{array}$ & $\begin{array}{c}1.6 \\
\pm 0.028\end{array}$ & $\begin{array}{c}0.86 \\
\pm 0.015\end{array}$ & $\begin{array}{c}22 \\
\pm 1.154\end{array}$ & $\begin{array}{c}1.29 \\
\pm 0.068\end{array}$ & $\begin{array}{c}32 \\
\pm 0.577\end{array}$ & $\begin{array}{c}0.91 \\
\pm 0.016\end{array}$ & $\begin{array}{c}1.88 \\
\pm 0.034\end{array}$ & $\begin{array}{c}0.82 \\
\pm 0.015\end{array}$ \\
\hline $50 \%$ & $\begin{array}{c}39.33 \\
\pm 0.333\end{array}$ & $\begin{array}{c}1.40 \\
\pm 0.011\end{array}$ & $\begin{array}{c}1.88 \\
\pm 0.010\end{array}$ & $\begin{array}{c}0.77 \\
\pm 0.004\end{array}$ & $\begin{array}{c}37 \\
\pm 1.154\end{array}$ & $\begin{array}{c}1.54 \\
\pm 0.048\end{array}$ & $\begin{array}{c}1.85 \\
\pm 0.057\end{array}$ & $\begin{array}{c}0.99 \\
\pm 0.031\end{array}$ & $\begin{array}{c}32 \\
\pm 0.866\end{array}$ & $\begin{array}{c}1.88 \\
\pm 0.050\end{array}$ & $\begin{array}{c}50.83 \\
\pm 0.166\end{array}$ & $\begin{array}{c}1.45 \\
\pm 0.004\end{array}$ & $\begin{array}{c}2.99 \\
\pm 0.019\end{array}$ & $\begin{array}{c}1.30 \\
\pm 0.004\end{array}$ \\
\hline $75 \%$ & $\begin{array}{c}47 \\
\pm 0.577\end{array}$ & $\begin{array}{c}1.67 \\
\pm 0.020\end{array}$ & $\begin{array}{c}2.23 \\
\pm 0.027\end{array}$ & $\begin{array}{c}0.92 \\
\pm 0.011\end{array}$ & $\begin{array}{c}45 \\
\pm 1.154\end{array}$ & $\begin{array}{c}1.87 \\
\pm 0.048\end{array}$ & $\begin{array}{c}2.25 \\
\pm 0.014\end{array}$ & $\begin{array}{c}1.21 \\
\pm 0.031\end{array}$ & $\begin{array}{c}38 \\
\pm 0.577\end{array}$ & $\begin{array}{c}2.23 \\
\pm 0.034\end{array}$ & $\begin{array}{c}55.33 \\
\pm 0.333\end{array}$ & $\begin{array}{c}1.58 \\
\pm 0.009\end{array}$ & $\begin{array}{c}3.25 \\
\pm 0.010\end{array}$ & $\begin{array}{c}1.41 \\
\pm 0.008\end{array}$ \\
\hline $100 \%$ & $\begin{array}{c}51.33 \\
\pm 0.333\end{array}$ & $\begin{array}{c}1.83 \\
\pm 0.012\end{array}$ & $\begin{array}{c}2.45 \\
\pm 0.010\end{array}$ & $\begin{array}{c}1.01 \\
\pm 0.004\end{array}$ & $\begin{array}{c}57 \\
\pm 0.288\end{array}$ & $\begin{array}{c}2.37 \\
\pm 0.011\end{array}$ & $\begin{array}{c}2.85 \\
\pm 0.014\end{array}$ & $\begin{array}{c}1.54 \\
\pm 0.007\end{array}$ & $\begin{array}{c}45 \\
\pm 0.577\end{array}$ & $\begin{array}{c}2.64 \\
\pm 0.033\end{array}$ & $\begin{array}{c}63.83 \\
\pm 0.166\end{array}$ & $\begin{array}{c}1.82 \\
\pm 0.005\end{array}$ & $\begin{array}{c}3.74 \\
\pm 0.01\end{array}$ & $\begin{array}{c}1.63 \\
\pm \\
0.004\end{array}$ \\
\hline
\end{tabular}

IZ=Inhibition zone including $6 \mathrm{~mm}$ diameter of filter paper disc; $\mathrm{Al}=$ activity index; $\mathrm{TC}=$ test compound, inhibition zones of standard griseofulvin (G) against $T$. rubrum $=28 \pm 0.577 \mathrm{~mm}$; $T$. simii $=24 \pm 0.577 \mathrm{~mm}$; C. tropicum $=35 \pm 1.154 \mathrm{~mm}$. Inhibition zones of standard itraconazole (I) against T. rubrum $=21 \pm 0.577 \mathrm{~mm}$; T. simii $=20 \pm 0.577 \mathrm{~mm}$; C. tropicum $=17 \pm 0.577 \mathrm{~mm}$. Inhibition zones of standard ketoconazole $(\mathrm{K})$ against $T$. rubrum $=51 \pm 0.577 \mathrm{~mm} ;$ T. simii $=37 \pm 1.154 \mathrm{~mm} ;$ C. tropicum $=39 \pm 1.154 \mathrm{~mm} ;$ C. indicum $=17 \pm 0.577$ 
attributable to the presence of phenolic compounds such as thymol and to hydrocarbons like g-terpinene and p-cymene ${ }^{[24]}$. p-Cymene $(24.02 \%)$ was found to be the second most common and abundant component of essential oil followed by $\gamma$-terpinene (13.77 \%). According to Delgado ${ }^{[25]}$, cymene does not have antimicrobial activity, but it increases the activity of phenolic compounds including thymol by swelling of the cytoplasmic membrane. Sharifzadeh et al. ${ }^{[26]}$ also reported thymol as a major component of $T$. ammi

TABLE 3: MIC OF ESSENTIAL OILS AGAINST SELECTED FUNGI

\begin{tabular}{cc}
\hline Fungi & T. ammi MIC $(\mu \mathrm{l} / \mathrm{ml})$ \\
\hline Candida albicans & $0.20 \pm 0.000$ \\
Microsporum gypseum & $0.5 \pm 0.000$ \\
Microsporum canis & $0.05 \pm 0.000$ \\
Trichophyton rubrum & $0.025 \pm 0.000$ \\
Trichophyton verrucosum & $0.025 \pm 0.000$ \\
Microsporum fulvum & $0.266 \pm 0.033$ \\
Fusarium verticilloides & $0.233 \pm 0.033$ \\
\hline
\end{tabular}

essential oil. Similar reports were also observed by Moazeni et al. ${ }^{[22]}$, Thangam and Dhananjayan ${ }^{[21]}$. Sharma and Swati ${ }^{[27]}$ also studied the GC-GC/MS analysis of $T$. ammi oil and found thymol as a major component.

The antidermatophytic activity of $T$. ammi essential oil was evaluated through the measurement of zone of inhibition, activity index and MIC. The correlation between two different methods examined was to be the larger inhibition zone correlated with lower MIC value. In present investigation, all the four concentration exhibited excellent antidermatophytic activities as compared to standard allopathic drugs itraconazole, ketoconazole and griseofulvin. MIC ranged from 0.025 to $0.5 \mu \mathrm{l} / \mathrm{ml}$ against selected fungi. Fraction separation of essential oil on the basis of boiling temperature of compounds through the glass oven equipment is a new field of work. No work has been reported on screening of essential oil fractions against any bacteria and fungi. The oil fractions obtained from the glass oven

TABLE 4: MIC OF T. AMMI FRACTIONS AGAINST DERMATOPHYTES

\begin{tabular}{lccccc}
\hline Fraction/fungi & $\mathrm{TA}^{\mathrm{I}}$ & $\mathrm{TA}^{\mathrm{II}}$ & $\mathrm{TA}$ & $\mathrm{TA}^{\mathrm{II}}$ & $\mathrm{TA}^{\mathrm{V}}$ \\
\hline Candida albicans & $0.433 \pm 0.033$ & $0.533 \pm 0.033$ & $0.233 \pm 0.033$ & $0.053 \pm 0.003$ & $0.05 \pm 0.003$ \\
Microsporum gypseum & $0.233 \pm 0.033$ & $0.1 \pm 0.033$ & $0.053 \pm 0.003$ & $0.026 \pm 0.002$ & $0.015 \pm 0.002$ \\
Microsporum canis & $0.333 \pm 0.033$ & $0.333 \pm 0.033$ & $0.133 \pm 0.033$ & $0.133 \pm 0.033$ & $0.017 \pm 0.002$ \\
Trichophyton rubrum & $0.233 \pm 0.033$ & $0.233 \pm 0.033$ & $0.050 \pm 0.000$ & $0.050 \pm 0.000$ & $0.020 \pm 0.000$ \\
\hline
\end{tabular}

TABLE 5: THE ACUTE DERMAL IRRITATION ASSAY ON ALBINO MICE

\begin{tabular}{|c|c|c|c|c|c|c|c|c|}
\hline \multirow[t]{2}{*}{ No. of mice } & \multicolumn{2}{|c|}{$1 \mathrm{~h}$} & \multicolumn{2}{|c|}{$24 \mathrm{~h}$} & \multicolumn{2}{|c|}{$48 \mathrm{~h}$} & \multicolumn{2}{|c|}{$72 \mathrm{~h}$} \\
\hline & Erythema & Edema & Erythema & Edema & Erythema & Edema & Erythema & Edema \\
\hline \multicolumn{9}{|c|}{$3 \%$ T. ammi oil } \\
\hline 1 & 0 & 0 & 0 & 0 & 0 & 0 & 0 & 0 \\
\hline 2 & 0 & 0 & 0 & 0 & 0 & 0 & 0 & 0 \\
\hline 3 & 0 & 0 & 0 & 0 & 0 & 0 & 0 & 0 \\
\hline 4 & 0 & 0 & 0 & 0 & 0 & 0 & 0 & 0 \\
\hline 5 & 0 & 0 & 0 & 0 & 0 & 0 & 0 & 0 \\
\hline \multicolumn{9}{|c|}{$5 \%$ T. ammi oil } \\
\hline 1 & 0 & 0 & 0 & 0 & 0 & 0 & 0 & 0 \\
\hline 2 & 0 & 0 & 0 & 0 & 0 & 0 & 0 & 0 \\
\hline 3 & 1 & 0 & 1 & 0 & 0 & 0 & 0 & 0 \\
\hline 4 & 1 & 0 & 2 & 0 & 1 & 0 & 0 & 0 \\
\hline 5 & 1 & 0 & 2 & 0 & 1 & 0 & 0 & 0 \\
\hline \multicolumn{9}{|c|}{$7 \%$ T. ammi oil } \\
\hline 1 & 1 & 0 & 2 & 0 & 2 & 0 & 1 & 0 \\
\hline 2 & 1 & 0 & 2 & 0 & 2 & 0 & 1 & 0 \\
\hline 3 & 2 & 0 & 2 & 0 & 2 & 0 & 1 & 0 \\
\hline 4 & 2 & 0 & 2 & 0 & 2 & 0 & 1 & 0 \\
\hline 5 & 2 & 0 & 2 & 0 & 2 & 0 & 1 & 0 \\
\hline
\end{tabular}

Erythema was scored as follows; no erythema $=0$, very slight erythema (barely perceptible) $=1$, well defined erythema $=2$, moderate to severe erythema $=3$, severe erythema (beet redness) to slight eschar formation (injuries in depth) $=4$. Edema formation was scored as follows no edema $=0$, very slight edema $=1$, sight edema (edges of area well-defined by definite raising)=2, moderate edema (raised approximately 1 $\mathrm{mm}$ ) $=3$, severe edema (raised more than $1 \mathrm{~mm}$ and extending beyond area of exposure) $=4$ 
TABLE 6: ALLERGENICITY RATING (ERYTHEMA) WITH T. AMMI OIL

\begin{tabular}{lcc}
\hline Concentration & Grade & Classification \\
\hline $1 \%$ & I & Non-irritant \\
$2 \%$ & I & Non-irritant \\
$3 \%$ & I & Non-irritant \\
$5 \%$ & II & Negligible irritation \\
$7 \%$ & III & Mild irritation \\
\hline
\end{tabular}

equipment were further subjected for MIC also showed excellent antidermatophytic properties. Five different fractions of T. ammi were separated and labelled as $\mathrm{TA}^{\mathrm{I}}-\mathrm{TA}^{\mathrm{V}}$. Among all these fractions, $\mathrm{TA}^{\mathrm{V}}$ showed more prominent fungicidal activities. $\mathrm{TA}^{\mathrm{V}}$ was separated at $240^{\circ}$ temperature. This fraction contained high concentration of thymol with other trace compounds. Boling point of thymol is $232.9^{\circ}$. Presence of thymol enhanced the antimicrobial activity of this fraction augmented manifold. Previous studies showed that thymol has a high microbicidal and antiaflatoxigenic effects due to the presence of phenolic $-\mathrm{OH}$ group ${ }^{[28]}$. $\mathrm{TA}^{\mathrm{I}}$ fraction was separated at $160^{\circ}$ contains less effective components like $\alpha$ pinene (boiling point 155 ) and $\beta$ pinene (boiling point $155-156^{\circ}$ ). Therefore $\mathrm{TA}^{\mathrm{I}}$ was found to be less effective as compared to any other fractions.

No work on acute dermal irritation of T. ammi has been reported till date. During present investigation, five concentrations of $T$. ammi oil were applied superficially on the skin of Swiss albino mice. Up to $3 \%$ concentration of oil no adverse side effect was observed. Slightly inflammation and redness were observed at $5 \%$ concentration, which disappeared at later hours. PDII score of $5 \%$ oil was found to be 0.5 while in presence of $7 \%$ oil 1.65 PDII score was recorded. Allergenicity rating classified 1-3\% oil as non-irritating category, $5 \%$ as negligible irritation and $7 \%$ as mild irritation category with grade III. This study unfolds that low concentration of oil had no toxic effects. No work on T. ammi dermal toxicity on mice and other animals has been reported till date. Craig et al. ${ }^{[29]}$ studied the western juniper oil and Port Orford cedar oil for possible dermal toxic effects on mice and rabbits. They used $0.5 \%$ and $5 \%$ concentration on shaved skin. Acute dermal irritation study using rabbits had a PII of 3.3 with $100 \%$ Port Orford cedar oil extract. This was reduced to a PII of 0.625 when diluted 1:1 with olive oil. Undiluted western juniper oil extract had a PII score of 2.7 while a $5.0 \%$ solution had a PII score of 0.3 , a $0.5 \%$ solution of western juniper oil was a non-irritant. Abdel et al ${ }^{[30]}$ studied the acute toxicity and irritancy of the essential oil of the leave of Vitex simplicifolia Oliv. and results thereof suggested that leaf essential oil of $V$. simplicifolia possessed slightly toxic and slightly irritancy activity. Very low MIC ranges of pure oil and its fractions and toxicity testing results reveal that up to $3 \% \mathrm{~T}$. ammi essential oil is safe for the preparation of ointment for the superficial treatment of fungal infection.

In summary, this study showed that low concentrations of oil exhibited no toxic side effects. Further, T. ammi oil did not elicit any hypersensitivity reactions nor would an acute skin irritation occur at the low concentration to which animals bedded on these materials be exposed. T. ammi oil exhibited excellent antidermatophytic activity as compared to standard allopathic drugs. Therefore, oil can be used for the treatment of tinea or ring worm infections as an alternate therapy.

\section{Acknowledgements:}

The authors thank the Head of the Botany Department, University of Rajasthan, Jaipur for providing laboratory facilities. They also thank the University Grant commission, New Delhi, India for providing financial assistance during research work (Award letter no 15-34/12(SA-II) dated 23.1.2012).

\section{Conflict of interest:}

No conflict of interest.

\section{Financial support and sponsorship:}

Nil.

\section{REFERENCES}

1. Ayurvedic Pharmacopoeia of India. Government of India, Ministry of Health and Family Welfare, Department of Ayush. Part 1 1999-2011;1:170-1.

2. Bhardwaj P, Alok U, Khanna A. In vitro cytotoxicity of essential oils. Int J Res Pharm Chem 2013;3:675-81.

3. Singh I, Singh VP. Antifungal properties of aqueous and organic extracts of seed plants against Aspergillus flavus and A. niger. Phytomorphol 2000;20:151-7.

4. Singh V, Ali M, Saxena R, Shekhar C, Deepika A. Volatile constituents and antimicrobial and antifungal activity of immature green seeds of Trachyspermum ammi. J Essent Oil Bear Pl 2008;11:120-3.

5. Paul S, Dubey RC, Maheshwari DK, Kang SC. Trachyspermum ammi (L.) fruit essential oil influencing on membrane permeability and surface characteristic in inhibiting food borne pathogen. Food Control 2011;22:725-31.

6. Umar S, Asif M, Sajad Mir, Ansari M, Hussain U, Ahmad $\mathrm{W}$, et al. Antiinflammatory and antioxidant activity of Trachyspermum ammi seeds in collagen induced arthritis in rats. Int J Drug Dev Res 2012;4:210-19. 
7. Seo SM, Kim J, Lee SG, Shin CH, Shin SC, Park IK. Fumigant Antitermitic Activity of Plant Essential Oils and Components from Ajowan (Trachyspermum ammi), Allspice (Pimenta dioica), Caraway (Carum carvi), Dill (Anethum graveolens), Geranium (Pelargonium graveolens) and Litsea (Litsea cubeba) Oils against Japanese Termite (Reticulitermes speratus Kolbe). J Agric Food Chem 2009;57:6596-602.

8. Roy S, Chaurvedi P, Chowdhary A. Evaluation of antiviral activity of essential oil of Trachyspermum ammi against Japanese encephalitis virus. Pharmacognosy Res 2015;7:263-7.

9. Pozzatti P, Scheid LA, Spader TB, Atayde ML, Santurio $\mathrm{JM}$, Alves SH. In vitro activity of essential oils extracted from plants used as spices against fluconazole resistant and fluconazole susceptible Candida spp. Can J Microbiol 2008;54:950-6.

10. Lateef M, Iqbal Z, Akhtar MS, Jabbar A, Khan MN, Gilani AH. Preliminary screening of Trachyspermum ammi (L.) seed for anthelmintic activity in sheep. Trop Anim Health Prod 2006;38:491-6.

11. Ahsan SK, Shah AH, Tanira MOM, Ahmad MS, Tariq M, Ageel AM. Studies on some herbal drug used against kidney stone in Siddhi folk medicine. Fitoterapia 1990;61:435-8.

12. Bhadauria S, Jain N, Sharma M, Kumar P. Dermatophytosis in Jaipur: study of incidence, "clinical features and causal agents". Indian J Microbiol 2001;41:207-10.

13. Lohoué Petmy J, Lando AJ, Kaptue L, Tchinda V, Folefack M. Superficial mycoses and HIV infection in Yaounde. J Eur Acad Dermatol Venereol 2004;8:301-4.

14. Karmakar S, Kalla G, Joshi KR. Dermatophytosis in a desert district of western Rajasthan. Indian J Dermatol Venereol Leprol 1995;61:280-3.

15. Neetu Jain, Sharma M, Meenakshi Sharma, Saxena VN. Spectrum of dermatophytoses in Jaipur, India. Afr J Microbiol Res 2014;8:237-43.

16. Vanbreuseghem R. Technique biologique pour l'isolment des dermatophytes du sol (Biological technique for the isolation of dermatophytes from the soil). Ann Soc Belg Med Trop 1952;32:173-8.

17. Wannisorn B, Jariksam S, Soontorntanasart T. Antifungal activity of lemon grass and lemon grass oil cream. Phytotherapy Res 1996;10:551-4.

18. Provine H, Hadley S. Preliminary evaluation of a semisolid agar antifungal susceptibility test for yeast and molds. J Clin Microbiol 2002;38:537-41.
19. Draize J H. The Appraisal of Chemicals in Foods, Drugs and Cosmetics. Austin, Texas: Association of Food and Drug Officials of the United States; 1959. p. 36-45.

20. Safaei-Ghomi J, Ahd AA. Antimicrobial and antifungal properties of the essential oil and methanol extracts of Eucalyptus largiflorens and Eucalyptus intertexta. Pharmacogn Mag 2010;9:172-5.

21. Thangam C, Dhananjayan R. Antiinflammatory potential of the seeds of Carum copticum. Indian J Pharmacol 2003;35:388-91.

22. Moazeni M, Saharkhiz MJ, Hosseini AA. In vitro lethal effect of ajowan, Trachyspermum ammi, essential oil on hydatid cyst protoscoleces. Vet Parasitol 2012;187:203-8.

23. Mohagheghzadeh A, Faridi P, Ghasemi Y. Carum copticum Benth. and Hook., Essential Oil Chemotypes. Food Chem 2007;100:1217-9.

24. Vardar-Unlu G, Candan F, Sokmen A, Daferera D, Polissiou $\mathrm{M}$, Sokmen M, et al. Antimicrobial and antitoxic activity of the essential oil and methanol extracts of Thymus pectinatus Fisch. et Mey.var. pectinatus (Lamiaceae). J Agric Food Chem 2003;51:63-7.

25. Delgado B, Fernández PS, Palop A, Periago PM. Effect of thymol and cymene on Bacillus cereus vegetative cells evaluated through the use of frequency distributions. Food Microbiol 2004;21:327-34.

26. Sharifzadeh A, Khosravi AR, Shokri H, Sharafi G. Antifungal effect of Trachyspermum ammi against susceptible and flucoazole resistant strains of Candida albicans. J Mycol Med 2015;25:143-150.

27. Sharma R, Swati. Antidermatophytic activity and gas chromatography of essential oils. Am J Phytomed Clin Therap 2014;2:430-41.

28. Farag RS, Daw ZY, Abo-raya SH. Influence of some spice essential oil on Aspergillus parasiticus growth and prduction of aflatoxins in a synthetic medium. J Food Sci 1989;54:74-6.

29. Craig AM, Karchesy JJ, Blythe LL, del Pilar GonzálezHernández M, Swan LR. Toxicity studies on western juniper oil (Juniperus occidentalis) and Port-Orford-cedar oil (Chamaecyparis lawsoniana) extracts utilizing local lymph node and acute dermal irritation assays. Toxicol Lett 2004;154:217-24.

30. Abdel MO, Noya S, Jean K, Sylvin O, Guissou IP. Acute Toxicity and Irritancy of the Essential Oil of the Leaves of Vitex simplicifolia Oliv. (Verbenaceae) in Burkina Faso. J Pharm Toxicol 2014;9:62-7. 